\title{
THE ASSISTANCE OF MANORS TO PEASANTS IN CASES OF SUBSISTENCE CRISIS IN SEVENTEENTH-CENTURY LIVONIA*
}

\begin{abstract}
Marten SEPPEL
University of Tartu, Department of History, Ülikooli 18, 50090 Tartu, Eesti; marten@ut.ee

This article aims to offer through the example of seventeenth-century Livonia an empirical look at the thesis that the lords of the manor offered their peasants insurance against the frequent subsistence crises. The article shows that in Gutsherrschaft Livonia the landlords' subsistence guaranty meant, as a rule, the practice of giving advance loans and allowing of arrears to the peasants. However, the peasantry took loans given by the manor, and the fact how the lord complied with their needs could explain their attitude towards the lord of the manor.
\end{abstract}

In 1660-1661 a lawsuit between the landowner and a leaseholder of manor Allasch (Allaži, near Riga) took place at a Livonian county court. The estate was granted on lease in 1659 but already in the first year the expenses of the manor had gone up enormously and as it appeared, the leaseholder had supported the peasants by giving them advance loans to the extent that was out of the ordinary, namely for 462 reichsthalers and 40 grosses (see Table 1). ${ }^{1}$ By way of comparison, at the same time according to the lease contract the rent for the first year had been 300 reichsthalers. ${ }^{2}$ During the years 1659 and 1660 almost all households (42 in all) in Allasch had got larger or smaller loans from the manor. And so the tenant farmers were called before the court to affirm the loans they had received. But then something remarkable happened. The peasants of Allasch stated their strong support for the leaseholder before the court, although as far as the record enables us to conclude, they were not directly questioned about their attitude towards the leaseholder.

Ruge Mieckell expressed the strong wish ("wündsche dahero nichts liebers") that he could have continued with the same lord, i.e. the present leaseholder,

\footnotetext{
I owe special thanks to Dr. Paul S. Warde who patiently helped me to correct my poor English and provided generous guidance.

1 Livländischer General-Gouverneur aus der schwedischen Zeit (1570-1710): Akten 1661. Estonian Historical Archives (= EHA), 278-1-XVI: 9, ff. 35v-39r.

2 Livländischer General-Gouverneur aus der schwedischen Zeit (1570-1710): Akten 1659. EHA, 278-1-XVI: 7, f. 62r.
} 
because the latter had given him help. He affirmed that he had got a horse, a cow and a goat plus two reichsthalers and added that if he had not been helped by the leaseholder he would not have been a peasant anymore. 'To be a peasant' meant to be a tenant farmer, as another peasant similarly stated - if the lord had not helped him he would have been a ruined man (ein verdorbener Kerll). Similarly many other peasants declared before the court their satisfaction and support to the leaseholder. Lepesall Jack with his stepson wanted to stay under the existing lord and pointed out that only God could know whether a new lord would help the poor men. Klietz Martin said that he did not want any other or a new lordship. The same claimed also the next peasant. Diedrich Kluge did not wish any other or even a better lord. ${ }^{3}$

The example of Allasch, however, shows the extraordinary and difficult situation in the country during these years. In addition to direct military actions that took place during the war between Sweden, Russia and Poland in 1655-61, immediately affecting Allasch because of its closeness to Riga, also high state taxes (due to extra taxes) and frequent passing of soldiers were damaging for the peasants. All this had brought the peasantry into a subsistence crisis.

In seventeenth-century Livonia, as elsewhere in Europe in addition to the general political and economic instability the weather conditions played a central role in rural society. Not only cold and wet summers, but also extreme droughts frequently caused bad harvests in that period, especially when keeping in view the general low agrotechnical level. Indeed, 'the little ice age' has often been regarded as a part of the concept of 'the seventeenth-century crisis'. Thus, subsistence crises were frequent among peasants during the period in question and living on the edge of subsistence meant that any unexpected or extraordinary claim might make a crop insufficient, even if in a normal year the crop itself was sufficient for subsistence (i.e. for bread and seed). ${ }^{4}$

However, like in all rural societies, it was very important in the Gutsherrschaft society that some basic pattern would function to make it possible for the peasantry to cope with these frequent crises. Traditionally, the marginal tenant, sharecropper, or tied labourer looked to his landlord for social insurance against periodic subsistence crises, as J. Scott has pointed out. It had been the general view that the social order should guarantee a man and his family subsistence. The claim 'right to subsistence' or even the 'right to a living' constituted one of the fundamental social moral principles of pre-capitalist order.

3 EHA, 278-1-XVI: 9, ff. 39v-41r.

${ }^{4}$ Scott, J. C. Political clientelism: A bibliographical essay. Friends, followers, and factions. A reader in political clientelism. Ed. S. W. Schmidt et al. Berkely and London, 1977, 29.

5 Scott, J. Patronage or exploitation? - Patrons and clients in Mediterranean societies. Ed. E. Gellner and J. Waterbury. Duckworth, 1977, 30-31; see also Scott, J. C. The moral economy of the peasant. Rebellion and subsistence in Southeast Asia. New Haven and London, 1976, 2-4; Blickle, R. From subsistence to property: Traces of a fundamental change in early modern Bavaria. - Central European History, 1992, 25, 379-382; Henningsen, P. Peasant society and the perception of a moral economy. Redistribution and risk aversion in traditional peasant culture. - Scandinavian Journal of History, 2001, 26, 282. 
Hitherto in the literature on serfdom the subsistence support mechanism between landlord and his serfs has had a rather marginal position. One of the main grounds for this, of course, is the fact that for a long time the Gutsherrschaft society has been mostly studied through the aspect of how the lord of the manor exploited and oppressed the peasants, and so the reciprocal issues have stayed in the background. ${ }^{6}$

Nevertheless, the problem of guaranteeing the peasant subsistence in the framework of serf society has not been totally unnoticed either. The landlord's commitment to support his peasants in cases of crop failures and dearth, which was one of his main obligations, has been mentioned ever more during the last decades. ${ }^{7}$ Making an attempt to reassess Russian serfdom, D. Moon has argued that on occasions when the harvest failed, it was in the interests of the nobles and the state to make sure that serfs were guaranteed subsistence. The serfs, in return, expected them to do so and, occasionally, protested if they did not. As a rule, the elites in Russia had indeed offered serf peasants some protection against starvation and this fact clearly contributed to the longevity of serfdom. ${ }^{8}$ Similarly $\mathrm{W}$. Prange has raised such issues in his works on manor-peasantry relations in Schleswig-Holstein. ${ }^{9}$ According to him the 'conservation of the subjects' (die Konservation der Untertanen) was a key word for the understanding of the manorial system. Guaranteeing manpower for the manor needed the mechanism of the conservation of the peasants and so it was an economic necessity in the manorial interest. In this respect, W. Prange finds, the manorial system with peasants'

${ }^{6}$ For the stereotypes in the Gutsherrschaft literature see the works of the school of Potsdam, in particular Peters, J. Gutsherrschaftsgeschichte in historisch-anthropologischer Perspektive. Gutsherrschaft als soziales Modell. Vergleichende Betrachtungen zur Funktionsweise frühneuzeitlicher Agrargesellschaften. Ed. J. Peters (Historische Zeitschrift, Beiheft, 18.) München, 1995, 3-21.

7 See Klußmann, J. Einleitung. Leibeigenschaft: Bäuerliche Unfreiheit in der frühen Neuzeit. Ed. J. Klußmann. Köln/Weimar/Wien, 2003, xiv; Bartlett, R. Serfdom and state power in Imperial Russia. - European History Quarterly, 2003, 33, 30; Laur, M. Eesti ala valitsemine 18. sajandil (1710-1783). [The administration of the Estonian territory in the 18th century (1710-1783)]. Tartu, 2000, 163-164; Laur, M. and Pirsko, P. Die Aufhebung der adligen Bevormundung in Liv- und Estland. Eine Besonderheit der Bauernbefreiung im Russischen Reich. Beiträge zur Geschichte des Ostseeraumes. Ed. H. Wernicke. (Greifswalder Historische Studien 4.) Hamburg, 2002, 103-118; Kahk, J. Bauer und Baron im Baltikum. Tallinn, 1999, 144.

8 Moon, D. Reassessing Russian serfdom. - European History Quarterly, 1996, 26, 503-506; see also Klußmann, J. Leibeigenschaft im frühneuzeitlichen Schleswig-Holstein: Rechtliche Entwicklung, öffentlicher Diskurs und bäuerliche Perspektive. Leibeigenschaft: Bäuerliche Unfreiheit in der frühen Neuzeit. Ed. J. Klußmann. Köln/Weimar/Wien, 2003, 238-240.

9 Most compactly in his brief article: Prange, W. Das Adlige Gut in Schleswig-Holstein im 18. Jahrhundert. Staatsdienst und Menschlichkeit. Studien zur Adelskultur des späten 18. Jahrhunderts in Schleswig-Holstein und Dänemark. Ed. Ch. Degn and D. Lohmeier. (Kieler Studien zur deutschen Literaturgeschichte 14.) Neumünster, 1980, 57-75; see also Prange, W. Flucht aus der Leibeigenschaft. Das Recht der kleinen Leute. Beiträge zur rechtlichen Volkskunde. Festschrift für K.-S. Kramer zum 60. Geburtstag. Ed. K. Köstlin and K. D. Sievers. Berlin, 1976, 166. 
serfdom and the manor lords' commitment to conservation could be regarded as a relationship based on reciprocity, which was a silent mutual contract. ${ }^{10}$

On the whole, the present paper shares the same starting-point, i.e. the working society had to include some basic patterns of how peasants could cope with frequent subsistence crises. However, all such statements need empirical verification since often the simple generalizations tend to be based more on logic or some arbitrarily selected examples rather than a careful factual basis. Hitherto there are no researches where the aspects of manorial subsistence support would be analytically precisely tackled.

Therefore, the aim of the following paper is an attempt to offer through a regional case study of seventeenth-century Livonia an empirical look at the thesis that the lords of the manor offered their subjects insurance against dearth. How did this function? However, the present paper does not try to refute the basic framework of landlord-serf relationship. It is clear that serfdom was based more or less on economic and social coercion. The aim is rather to look for these aspects in rural society that actually helped peasants to cope, on the one hand, with the instability of weather conditions, and on the other hand with the high demands on their production by the lord.

\section{CREDIT MECHANISM}

The fact that in general the peasants in Livonia indeed found support from the manor in the cases of subsistence crises becomes evident from many sources of that time. However, they also demonstrate clearly that landlords assisted their peasants, as a rule, not by giving gifts but giving only credit (so-called advance loans, Vorstreckungen) that was expected to be paid back as far as possible. ${ }^{11}$

10 Prange, W. Das Adlige Gut, 67-68.

11 The role of credit relations in the rural economy in the whole of Europe has increasingly been discussed, see Boelcke, W. A. Zur Entwicklung des bäuerlichen Kreditwesens in Württemberg vom späten Mittelalter bis Anfang des 17. Jahrhunderts. - Jahrbücher für Nationalökonomie und Statistik, 1964, 176, 319-358; Holderness, B. A. Credit in English rural society before the nineteenth century, with special reference to the period 1650-1720. - The Agricultural History Review, 1976, 24, 97-109; Weisser, M. R. Rural crisis and rural credit in XVII-century Castile. The Journal of European Economic History, 1987, 16, 297-313; Poulsen, B. 'Alle myne rent'. Bondekredit i 15-16-tallet. - Historisk Tidsskrift, 1990, 90, 247-275; Boelcke, W. A. Der Agrarkredit in deutschen Terriorialstaaten vom Mittelalter bis Anfang des 18. Jahrhunderts. Kredit im spätmittelalterlichen und frühneuzeitlihen Europa. Ed. M. North. (Quellen und Darstellungen zur Hansischen Gescichte 37.) Köln and Wien, 1991, 193-216; Wunder, H. Finance in the 'economy of Old Europe': The example of peasant credit from the late middle ages to the Thirty Years War. Wealth and taxation in Central Europe. The history and sociology of public finance. Ed. P.-Ch. Witt. Leanington, 1987, 24-48; see also the special issue of the journal Annales: Histoire, Scienes Sociales, 49 (1994) dedicated to "Les réseaux de crédit en Europe, XVIe-XVIIIe siécles". 
Such credit relations were based first of all on natural economy, though sometimes the share of money could also be significant. ${ }^{12}$ The basic loan article was still grain - rye and barley and also oats. ${ }^{13}$ According to an example of debt register of Borghoff (Borrishof), which indicates the peasants' debts during ca twentyfive years, the share of the advance grain for seed-corn was roughly 20 per cent higher than that for bread. ${ }^{14}$ The corn loans were typical in spring months and it has also been pointed out that often such grain used to be of bad quality or old, which was not well suited for market or sowing in the manor's field. ${ }^{15}$

However, not only corn but also livestock loans were very common. Most frequently the manor helped the peasants to procure horses but in fact cows almost as often (see Table 1). In addition, oxen, goats and sheep are mentioned several times in the inventories of peasant debts.

The peasants also received malt, hay and peas from the manor and several debt registers show that the lord had provided sometimes all the salt the peasants needed. For example on the manors near a body of water, where fish played a great role, such salt debts could be notably high. ${ }^{16}$ In addition to salt, iron, copper and brazen tools are mentioned in such debt lists. So, the peasants of Allasch owed the manor a pair of ploughshares and a copper kettle. ${ }^{17}$ On the whole manors became the connecting link between merchants and peasants. In Livonia that phenomenon became increasingly regular in the seventeenth century where despite the opposition of the state and towns, landlords practised buying and selling with their peasants so that town-peasant direct market relations were impeded. Sometimes they even kept little public shops where peasants could buy any kind of "trader's goods". ${ }^{18}$

12 On the manors close to towns money loans could be even dominant, see e.g. Vidzemes zviedru generālgubernatora kanceleja: Ikšķiles muizas ieņēmumu un izdevumu pārskati 1662-1663. Latvian State Historical Archives (= LSHA), 7349-2-50, 22-31.

13 Here I have used the debt registers on different manors of Livonia: EHA, 278-1-XVI: 9, ff. 35v-39r; Livländischer General-Gouverneur aus der schwedischen Zeit (1570-1710): Protokolle und Akten des Landgerichts Rigischen Kreises 1671/1674. EHA, 278-1-XV: 8, ff. 132r-139v; Livländischer General-Gouverneur aus der schwedischen Zeit (1570-1710): Acta de $\mathrm{A}^{\circ}$ 1663. EHA, 278-1-XVI: 11a-4, f. 88r-88v; LSHA, 7349-2-50, 22, 29-31; Vidzemes zviedru generālgubernatora kanceleja: Raksti par reducētām un valsts rentes muižam (16881698). LSHA, 7349-1-223, ff. 12r-13r, 20r-22r; Livländische Mess- und Revisionskommission (1565-1917): Verzeichnis der Bauern des Gutes Odenpäh-Schloss, die Korn vorgestrect haben (1768). EHA, 567-3-216, f. 1r-1v.

14 EHA, 278-1-XV: 8, ff. 132r-139v.

15 See Soom, A. Der Herrenhof in Estland im 17. Jahrhundert. Lund, 1954, 207.

16 E.g. in the manor Moisekatz three peasants owed an entire tun of salt (i.e. ca $165 \mathrm{~kg}$ ) to the manor (Livländischer General-Gouverneur aus der schwedischen Zeit (1570-1710): Akten 1662. EHA, 278-1-XVI: 10a, 264-265).

17 EHA, 278-1-XVI: 9, ff. 36r, 40r.

18 Eesti talurahva ajalugu. [History of Estonian Peasantry.] Ed. J. Kahk and E. Tarvel. Tallinn, 1992, 396-398. Attempts to create closed "markets" inside the estates in the seventeenth century can be similarly observed in Poland and probably elsewhere in Gutsherrschaft countries (see Maczak, A. Agricultural and livestock production in Poland: Internal and foreign markets. The Journal of European Economic History, 1972, 1, 672). 
Table 1. Loans given to peasants by the manor of Allasch in 1659/60

\begin{tabular}{l|c|c|c|c|r|r}
\hline \multirow{2}{*}{ Value } & \multirow{2}{*}{$\begin{array}{c}\text { Number of } \\
\text { households }\end{array}$} & \multirow{2}{*}{ Quantity } & \multicolumn{2}{c|}{ Total value } & \multicolumn{2}{c}{ Percentage } \\
\cline { 5 - 7 } & & $\begin{array}{c}\text { Reichs } \\
\text { thalers }\end{array}$ & Grosses & $\begin{array}{c}\text { By } \\
\text { occurrence }\end{array}$ & $\begin{array}{c}\text { By } \\
\text { value }\end{array}$ \\
\hline Rye & 23 & 47.5 & 47 & 45 & 17.8 & 10.3 \\
Barley & 9 & 8.5 & 6 & 54 & 6.9 & 1.4 \\
Oats & 6 & 7 & 3 & 66 & 4.6 & 0.8 \\
Horses & 30 & 35 & 213 & 65 & 24.8 & 46.2 \\
Cows & 32 & 32 & 136 & 80 & 24.8 & 29.6 \\
Goats & 3 & 3 & 2 & 30 & 2.3 & 0.5 \\
Sheep & 1 & 1 & 1 & 18 & 0.7 & 0.2 \\
Salt & 10 & 18.5 & 2 & 42 & 7.7 & 0.5 \\
Cash & 11 & - & 46 & 45 & 9.3 & 10.1 \\
Others & 1 & 1 & 1 & 45 & 0.7 & 0.3 \\
In all & 42 & - & 462 & 40 & 100 & 100
\end{tabular}

Note: Quantities of all cereals are in bushels $(1$ bushel = ca 691$)$; and of salt in liesspounds ( 1 liesspound $=20$ pounds $=8.4 \mathrm{~kg}$ ).

Source: EHA 278-1-XVI:9, ff. 35v-39r.

In every case, the surviving peasant debt registers kept by the manor clearly show that in some years peasants remained in debt more often than in other years. The fact that the debts rose after a bad harvest is, of course, not surprising. However, the specifications of peasants' advance loans show that credit relations between the manor and peasants were not frequent only in cases of crop failure, but smaller loans were even made annually. ${ }^{19}$

The need to get credit also in years of good harvest arose presumably from the excessive level of feudal rent or unexpected losses. It was also usual that a peasant paid his customary dues to the manor in autumn, but then suffered a lack of seed-corn or even of bread in spring and had to turn again to the manor for a loan. Indeed, there are known some examples where the bailiff or steward of the manor has been directly instructed that it is better to lend corn to the peasants in spring when needed than to allow arrears in the autumn. ${ }^{20}$ The idea was obviously a general conception about serf-peasants as farmers who had no sense of responsibility and interest in economizing. Making a concession over duties to them in autumn did not guarantee that there would be no need to support them in spring. However, the fact is that the sources of Livonia apply to the same problem W. W. Hagen has pointed out about Brandenburg-Prussia that actually we know

19 The same phenomenon has been pointed out about Polish agrarian relations: Rutkowski, J. The distribution of incomes in a feudal system. Ed. J. Topolski. Wroclaw, 1991, 72.

20 Dunsdorfs, E. The Livonian estates of Axel Oxenstierna. Stockholm, 1981, 40; Soom, A. Der Herrenhof, 207. 
little of how peasants used to divide their harvests between seed-grain, household consumption, feudal rent and possible sale. ${ }^{21}$

The debts of a farmstead were not tied to a fixed person but to a fixed household. It meant that after a tenant's death the burden of repayment transferred to the new household head. Thus some debt registers reveal the loans, which were not discharged over twenty-five years and which were taken by the preceding tenant and even given by the preceding landowner. ${ }^{22}$ However, it has to be stressed that on the other hand the peasants were far more capable of repaying their advance loans, and similarly the arrears, than has been often represented in the historiography. ${ }^{23}$

It is important as well that rural credit links were actually much wider than the credit relationships between landlord and peasant. So peasants often had life-long credit relations with a certain dealer in the closest town on whom they were dependent (so-called friend trade). Such debt dependence constituted practically a second dependence for the peasant. ${ }^{24}$ A. Soom, who has studied this topic the most, has supposed that peasants' debt dependence on an urban friend had usually begun when in cases of crop failure, cattle plague or war devastation the peasant had been in need for support from the town as his lord had not helped him. ${ }^{25}$ Obviously this was not the only origin and such credit relations between peasant and tradesman could also come into being through other market intercourses. However, the fact is that the peasants often got similar loans from the town as from the manor and that such debts grew in the years of bad harvest. But it remains unclear why the peasants occasionally favoured a tradesman instead of the manor as at the same time the examples can be found in the sources that the peasants had taken on credit from the town although their manor had been an active creditor as well. ${ }^{26}$

21 Hagen, W. W. Ordinary Prussians: Brandenburg junkers and villagers, 1500-1840. Cambridge, $2002,185$.

22 EHA, 278-1-XV: 8, f. 137v; see also Livländische Mess- und Revisionskommission (1565-1917): Gut Wieratz (Fellin). EHA 567-3-83, f. 15r.

23 See Soom, A. Der Herrenhof, 206; Tarvel, E. Der Haken: die Grundlagen der Landnutzung und der Besteuerung in Estland im 13.-19. Jahrhundert. Tallinn, 1983, 181; Öpik, E. Talurahva mõisavastane võitlus Eestis (Põhjasõja esimesel poolel 1700-1710). [Peasantry's struggle against manor in Estonia (in the first half of the Northern War 1700-1710)]. Tallinn, 1964, 22-23; Heyde, J. Bauer, Gutshof und Königsmacht. Die estnischen Bauern in Livland unter polnischer und schwedischer Herrschaft 1561-1650. Köln and Weimar, 2000, 239-240; see also e.g. Rathßhoff Restantien Register von Ao 1670 biß 15. Aprill Ao 1688. Svenska Riksarkivet (= RA), Ekonomisthållarens i Dorpat G.A. Strömfelts kontor: 23.

24 Soom, A. Der baltische Getreidehandel im 17. Jahrhundert. (Kungl. Vitterhets Historie och Antikvitets Akademiens Handlingar Historiske Serien 8.) Stockholm, 1961, 246, 260-263; Kahk, J. and Tarvel, E. An economic history of the Baltic countries. (Studia Baltica Stockhomiensia, 20.) Stockholm, 1997, 46-47; see also Jensch, G. Der Handel Rigas im 17. Jahrhundert. Ein Beitrag zur livländischen Wirtschaftsgeschichte in schwedischen Zeit. Mitteilungen aus der livländischen Geschichte, Bd. 24. Riga, 1930, 78-87.

25 Soom, A. Der baltische Getreidehandel, 261.

26 See e.g. Actus revisionis Livoniae 1638. Pars Latviae I, Ed. E. Dunsdorfs. (Latvijas Vēstures Avoti, 4.) Riga, 1938, 7-16. 
Alongside the 'friend trade', there were usually close peasant communal relationships in the villages, and so the peasants' mutual credit relations were also rather typical (mostly in kind). Sometimes parish pastors acted as creditors as well.

\section{SELF-INTERESTS AND EXPECTATIONS}

Answering the question of why the landlords supported their peasants, the most convincing explanation is that this was simply an economic transaction in order to maintain labour for their manorial enterprise. The fact that the lords of the manor indeed assisted the peasants, aiming at keeping the peasants resident ("conserving" the peasants), is shown directly in the sources. ${ }^{27}$ The peasant advance loans have been repeatedly seen as something important and unavoidable by the landlords. After an inquiry about the leaseholder of Allasch whose first year of lease expenses had been out of the ordinary, the county court conceded in its decision that though the total of advance payments spent on the peasantry by the leaseholder was remarkable, restoring again the peasants of the manor [had been] absolutely necessary, the manor had given the advance loans for its own good. ${ }^{28}$

Another question is whether credit was given to the peasantry by the manor on usurious conditions. The records on Livonian manors do not allow a clearer look at that problem. Usually there are no notes about the possible interest charge in the debt registers. However, some other sources from the same period show that taking interest was not unknown. For instance a joint peasants' written complaint to king Charles XI from the year 1685 shows that the leaseholder of the manor had demanded from them an additional one tun grain per every four tuns. ${ }^{29}$ After the great famine of 1695-1697 an order by the governor-general demanded that anybody on the crown estates had no right to take higher interest (Baht) from the peasantry than one-sixth of the loan. Everybody who transgressed could lose all advance loans granted to the peasants. ${ }^{30}$ Similarly, taking interest charges from the peasantry in Livonia is known from the eighteenth century. ${ }^{31}$ However, the lord of the manor did not lend grain, livestock or money only for the purpose

27 See e.g. Dunsdorfs, E. The Livonian estates, 99.

28 EHA, 278-1-XVI: 9, ff. 64r-65v; see also ibid. f. 12r-12v.

29 Soom, A. Der Herrenhof, 208.

30 Lieffländische Landes-Ordnungen nebst dazu gehörigen Placaten und Stadgen. Riga, 1707, 686. The rate of interest of 'seven instead of six' was indeed practiced on some Livonian crown estates at the end of the seventeenth century (see e.g. Vidzemes, Kurzemes un Igaunijas muižas: Cesvaines muiža (1626-1707). LSHA, 6999-12-10, 498-499).

31 See Arbusow, L. Das Bauernrecht des sog. Budberg-Schraderschen Landrechtsentwurfs von 1740 in ursprünglicher Gestalt. Mitteilungen aus der livländischen Geschichte, Bd. 25/4. Riga, 1937, 389-390; Merkel, G. Die Letten vorzüglich in Liefland am Ende des philosophischen Jahrhunderts. Ein Beitrag zur Völker- und Menschenkunde. Leipzig, 1797, 82; Laur, M. Eesti ala valitsemine, 163 . 
of usury. For the lord it was still more important to keep peasant households running. ${ }^{32}$

In some cases such loans can be taken directly for investments of a manor. The latter becomes manifest for example in the case of the small manor Wieratz (Viiratsi), which L. Wadenfeldt had acquired in 1658 but as he explained later, he had found only deserted land, without any peasants. ${ }^{33}$ So he had looked for and bought the peasants and had to advance horses, livestock and grain to them, as they were poor and had nothing. ${ }^{34}$

Giving corn and livestock to the peasants newly settled under the manor was usual in Livonia. At times the new settlers could even find support from the manor for building their new farmhouses. ${ }^{35}$ Also the practice of giving some free years to a new settler, as it was common in the regions of Germany, Sweden, Bohemia and elsewhere, ${ }^{36}$ had become such a rule in Livonia as well that it could be taken for a peasant's right. Numerous peasants' complaints have survived that regardless of their free years, the manor had demanded duties from them. ${ }^{37}$

The years free of duties and at the same time the support that the lords of the manors offered for new settlers were circumstances that favoured peasants' flight at the same time, especially in the first half of the seventeenth century when due to the war the number of deserted farmsteads was high. The reason for the peasants' resettlement was frequently only an attempt to find more favourable conditions for farming and to use the years free of duties. For example, as is known from the end of the sixteenth century at the borderlands of Russia, entire groups of peasants

$32 \mathrm{H}$. Wunder has similarly pointed out that it was so just because of a different understanding of the term 'interest'. The 'interest' of the lords was rather to preserve their power (Wunder, $\mathbf{H}$. Finance, 33-34). On the contrary A. Maczak has repeatedly emphasized the role of usury in rural credit relations in early modern Poland (Maczak, A. Kredyt w gospodarce. - Przeglad Historyczny, 1960, 51, 311; Maczak, A. Agricultural, 672; Maczak, A. Money and society in Poland and Lithuania in the 16th and 17th centuries. - The Journal of European Economic History, 1976, 5, 94; see also Rutkowski, J. The distribution, 72).

33 EHA, 567-3-83, f. 13r. According to the land revision of 1638 the manor Wieratz was inhabited by two households, both new settlers (Actus revisionis, 95). The inventory of Wieratz made out during the revision of 1690/91 shows 19 households inhabited (Östersjöprovinserna. Jordrevisions-handlingar (1687-1692). EHA, MF330, 238). EHA, 567-3-83, f. 13r; similarly also EHA, 278-1-XVI: 9, f. 197r-197v.

35 Soom, A. Der Herrenhof, 328.

36 See e.g. Maur, E. Gutsherrschaft und "zweite Leibeigenschaft" in Böhmen: Studien zur Wirtschafts-, Sozial- und Bevölkerungsgeschichte (14.-18. Jahrhundert). (Sozial- und wirtschaftshistorische Studien, 26.) München, 2001, 197; Hagen, W. W. Ordinary Prussians, 71; Enders, L. Emanzipation der Agrargesellschaft im 18. Jahrhundert - Trends und Gegentrends in der Mark Brandenburg. Konflikt und Kontrolle in Gutsherrschaftsgesellschaften. Über Resistenz- und Herrschaftsverhalten in ländlichen Sozialgebilden der Frühen Neuzeit. Ed. J. Peters. (Veröffentlichungen des Max-Planck-Instituts für Geschichte, 120.) Göttingen, 1995, 404; Jutikkala, E. Suomen talonpojan historia. [The history of Finnish peasantry, vol. 2.] Helsinki, 1958, 118.

37 See e.g. Livländischer General-Gouverneur aus der schwedischen Zeit (1570-1710): Akten 1649, 1651. EHA, 278-1-XVI: 4, f. 104v; Livländischer General-Gouverneur aus der schwedischen Zeit (1570-1710): Acta 1646. EHA, 278-1-XVI-3a, ff. 4v, 59r-60v, 62r. 
time and again changed their dwelling-place, living once on the one and then one the other side of the border, and so during a number of years took advantage of favoured duties. ${ }^{38}$

As it appears, giving credit to the peasants also carried many risks for the manor. It was not only the risk that the peasant might be not able to repay, but that a growing burden of debt might again give a good reason to the peasant to flee to another manor in order to become exempt from his old debts and at the same time find new support from the new manor and use the years free of duties. ${ }^{39}$ Such patterns could appear especially at times when the demand for labour was higher. A handbook about farming "Lieffländischer Landman" by J. Herman published in 1662 advises directly that a bailiff should not enable peasants to stay in debt, which eventually would only bring about their flight. ${ }^{40}$

However, both parties, the landlord and the peasantry, took loans given by the manor for help and support. ${ }^{41}$ The peasants saw the advance loans for help but simultaneously they were aware of their indebtedness, and that they were obliged to pay them back. For instance during the court case referred to at the beginning one peasant of Allasch confessed honestly before the court that his debts were actually bigger than the specification submitted to the court showed. Namely he had got not only a horse, a cow and grain from the lord as specified, but also a pair of ploughshares. ${ }^{42}$

In some cases, after falling into more serious debt, the peasants could even hope for partial or entire revoke. So, for example, in 1637 the steward of the Livonian possessions of the renowned Swedish statesman Axel Oxenstierna had asked the chancellor for advice about what to do if peasants had been unable to settle their debts. A. Oxenstierna had replied that in order to not impoverish the peasants totally, debts could be cancelled but without informing the peasants about it. ${ }^{43}$

As is known, A. Oxenstierna was himself influenced by paternalistic ideas one should treat peasants as a father would his children. ${ }^{44}$ In seventeenth-century

38 Тарвел Э. Фольварк, пан и подданный. Аграрные отношения в польских владенях на территории южной Эстонии в конце XVI-начале XVII века. Таллин, 1964, 121.

39 E.g. see a good instance: Latviešu dzimtlaužu bēgšana uz Rīgu I: no 1398. līdz 1708. gadam. [Latvian serfs' flight to Riga I: from 1398 to 1708.] Ed. V. Biļ̧̧ins and M. Kundziņa. Rīga, 1937, no. 172.

40 Herman, J. Lieffländischer Landman. Riga, 1662, 121.

41 Such understanding and wording was universal (see e.g. Liiv, O. Die grosse Hungersnot in Estland 1695-1697. (Academicae societatis historicae scripta, 9.) Tartu, 1938, passim; see also the 'Hans and Michel' dialogue in: Mancelius, G. Phraseologia Lettica, Das ist: Täglicher Gebrauch der Lettischen Sprache, part 2, Riga, 1638.

42 Inten Welling gestehet den auffsatz in totum, habe auch sonst überdem noch ein paar Pflügeisen bekommen, so Er der würde nach auch gerne hinkünffig bezahlen wolle (EHA, 278-1-XVI: 9, f. 40r).

43 Dunsdorfs, E. The Livonian estates, 94.

44 Englund, P. Det hotade huset: adliga föreställningar om samhället under stormaktstiden. Stockholm, 1989, 93. 
Livonia the paternalistic view was not unknown though as a propagated ideology and political rhetoric paternalism did not spread widely in the Baltic provinces before the second half of the eighteenth century. ${ }^{45}$ Another question is, of course, to what extent the real landlords' paternal concern for peasants occurred alongside economic interests. Any empirical demonstration of actual ideological implications of landlords' behaviour is more than complicated. However, it can be erroneous to ignore fully the ideological explanations for the landlords' actions (as e.g. Christian thought played a role in almsgiving to beggars).

In keeping with the spirit of the time, the church's arguments were used by the landlords as well as by the peasants, when fitting. On the one hand, giving assisting loans to the peasantry was clearly regarded as Christian behaviour by contemporaries. ${ }^{46}$ On the other hand, the peasantry sometimes referred to the Christian norms in their complaints when they failed to get the expected support from the lord of the manor. In 1645 a peasant of Adsel (Gaujiena) Johan Branck lamented against the leaseholder of the manor that the latter had not remitted him either corvée or dues, though his whole farmstead had burnt down and his harvest of rye and barley had all frozen. In brief, he accused the leaseholder of unchristian treatment. ${ }^{47}$ The leaseholder's reply was clear and full of economic rationalism before the assembled committee of inquiry: Not, that here I would have behaved unchristianly. For my part I wanted to remit something not only to him but also jointly to the others [peasants] if it would have been waived from my rent but that has not happened. ${ }^{48}$

In fact, in the many seventeenth-century written complaints the peasants had a clear grievance that their lord had not reduced their duties in cases of hardship. Similarly another peasant of Adsel described his situation - three years ago his corn had frozen and in consequence he could not pay his dues. Their merciful hereditary lord had been in the habit of waiving payments in such years to him as

45 For the role of paternalism in the framework of Gutsherrschaft, see Berdahl, R. Preußischer Adel: Paternalismus als Herrschaftssystem. Preußen im Rückblick. Ed. H.-J. Puhle and H.-U. Wehler. (Geschichte und Gesellschaft, Sonderheft, 6.) Göttingen, 1980, 122-145; Berdahl, R. M. The politics of the Prussian nobility. The development of a conservative ideology, 1770-1848. Princeton, 1988, in particular 44-45; Melton, E. The decline of Prussian Gutsherrschaft and the rise of the Junker as rural patron, 1750-1806. - German History, 1994, 12, 339-340; Kaak, H. Vermittelte, selbsttätige und maternale Herrschaft. Formen gutsherrlicher Durchsetzung, Behauptung und Gestaltung in Quilitz-Friedland (Lebus/Oberbarnim) im 18. Jahrhundert. Konflikt und Kontrolle in Gutsherrschaftsgesellschaften. Über Resistenz- und Herrschaftsverhalten in ländlichen Sozialgebilden der Frühen Neuzeit. Ed. J. Peters. (Veröffentlichungen des Max-Planck-Instituts für Geschichte, 120.) Göttingen, 1995, 111; Kaak, H. Diskussionsbericht. Gutsherrschaftsgesellschaften im europäischen Vergleich. Ed. J. Peters. Berlin, 1997, 523; Klußmann, J. Leibeigenschaft, 238-240.

46 See e.g. Liiv, O. Die grosse Hungersnot, 88; LSHA, 6999-12-10, 315.

47 In the record: nichts anders alß unchristlich mit ihme gehandelt ist; and in the other place: den Arrendatorn vor unchristlich beschuldiget (EHA, 278-1-XVI: 3a, ff. 3r, 60r).

48 Ibid., ff. $4 \mathrm{r}, 6 \mathrm{r}$. 
also to other peasants, but under the present leaseholder nothing happened. As he had been unable to give the required corn, the leaseholder had taken his oxen that he had not got back, even when he had remunerated fully his corn debt. ${ }^{49}$ It was rather typical of the peasants' complaints that the present lord was compared with the previous "good" lord. A new lord was frequently a new leaseholder, pawnee or buyer of the manor. J. Peters has similarly pointed out that the peasants often perceived clearly the change of the generation on the manor, which statement is backed in the Livonian peasant grievances as well. ${ }^{50}$

It is obvious that the peasants' relations with the manor depended on the personality of the lord to a large degree, his manner of management and mentality. There were distinctions even in the lord's relations with different peasants. There were more trusting relationships between some peasants and lords than between the others. As a matter of fact, in recent historiography the lords' individual differences have become increasingly noticed. ${ }^{51}$

The peasants content with their lord could even give him their support in return. The peasants' testimonies where they show their positive attitude towards their lord, as seen in the case of Allasch, were actually not very exceptional in the court practice of the time. ${ }^{52}$ Such attachment by the peasants could become a momentous argument for the leaseholders at the legal proceedings against them or in their own petitions about following the lease contract terms. For instance, in the years of the great famine of 1695-1697 the governor-general received a great number of supplications from the leaseholders of the numerous crown estates with the request to get permission to pay rent more flexibly. In them the argument was often used that despite everything, they had assisted the peasants, and in consequence no complaint from the peasants had been received. ${ }^{53}$

Giving support to the peasantry was one of the matters that in return could guarantee the peasants' increased favour. It also appears that the peasants were often sincerely afraid that their lord might not be able to assist them anymore, and

49 EHA, 278-1-XVI: 3a, ff. 5v, 28r-29r, 59r; for the practice of taking away cattle and other properties from the peasants in place of their corn dues, see Soom, A. Der Herrenhof, 208.

50 Peters, J. Eigensinn und Widerstand im Alltag. Abwehrverhalten ostelbischer Bauern unter Refeudalisierungsdruck. - Jahrbuch für Wirtschaftsgeschichte, 1991, 2, 90; see e.g. Estländischer General-Gouverneur aus der schwedischen Zeit: Allerhandt altte svpplicationes (1589-1644). EHA, 1-2-310, f. 19r.

51 Peters, J. Eigensinn und Widerstand, 90; Göttsch, S. “Alle für einen Mann...”. Leibeigene und Widerständigkeit in Schleswig-Holstein im 18. Jahrhundert. (Studien zur Volkskunde und Kulturgeschichte Schleswig-Holsteins, 24.) Neumünster, 1991, 106; Berdahl, R. Preußischer Adel, 134-135; see also Rösener, W. Adelsherrschaft als kulturhistorisches Phänomen. Paternalismus, Herrschaftssymbolik und Adelskritik. - Historische Zeitschrift, 1999, 268, 1-2.

52 See e.g. LSHA, 7349-1-223, 633-636; Livländischer General-Gouverneur aus der schwedischen Zeit (1570-1710): Acta de $\mathrm{A}^{\circ}$ : 1663. EHA, 278-1-XVI: 11a-2, ff. 92r-93r.

53 E.g. ...so bey Brod und andern Lebensmitteln, wordurch sie mir dann ein großes schuldig verblieben, mit meinem Schaden conserviret, daß bey wehren den ArrendsJahren keine beschwere und Klagten über mir geführet worden (LSHA, 7349-1-223, 568-9; 628). 
that would mean their impoverishment or even death in cases of greater crop failures. ${ }^{54}$ Similarly examples are known where the peasants indeed no longer got support any from the manor due to the fact that their debts were already very high. $^{55}$

\section{THE CASE OF THE GREAT FAMINE OF 1695-1697}

The greatest blow to the farm and manorial economy in seventeenth-century Livonia took place at the end of the century, in the years 1695-1697. As is well known, the extensive successive crop failures of the 1690s did not befall only the Baltic provinces, but almost the whole of Europe. The issue of the manors' will and ability to support their peasants came up on the agenda most acutely in these years.

The years 1695-1697 were one of the most severe periods of hardship in Livonia ever recorded. From 1696 the number of the dead from starvation grew drastically and from the first half of 1697 mortality hit crisis level. In all, the death rate of 1695-1697 in Livonia has been estimated at about 20 per cent of the population. During these years the warnings about starvation, peasants' flight and even a danger of peasants' rebellion were continually received. The anxiety that the result of this could be a vast desertion of the land spread everywhere. Indeed, on the estates where the peasants were not supported enough the farmsteads were deserted. There are many examples showing that the peasants tried to move to those manors where they found subsistence from the lord. ${ }^{56}$

In some places the peasants had fled not because of direct starvation but on account of the calculation that they would be never able to repay the loans taken during these years. ${ }^{57}$ The peasants had not fallen into great debt only from the manor but according to the town tradesmen's debt books, the peasants had also taken credit from the towns where they had pawned their silver brooches, rings and other valuables, as well as sold their cattle. ${ }^{58}$

54 As the assessor of the county court noted the anxiety of the peasants of manor Lais in the last year of the great famine of 1695-1697: Sonsten hätte die Herrschaft ihnen mit saat und brodt geholfen. [...] Ob sie aber hinführo weiter Hülfe von Sie haben werden wisen Sie nicht. [...] ietzo hetten Sie nicht mehr brodt, wüsten nicht, wo mit Sie ihr leben weiter aufhalten werden, Ihre Herschafft hette Sie allemahl mit Saat und Brodt geholfen, wan dieselbe nicht weiter helffen wirdt, so werden sie alle verderben (LSHA, 7349-1-223, 633-636).

55 See: Eesti rahva ajaloost Põhjasõja aastail (1700-1721): valimik dokumente. [On the history of Estonian nation in the years of the Northern War (1700-1721): a selection of documents] Ed.

R. Kenkmaa et al. Tallinn, 1960, no. 61.

56 See Liiv, O. Die grosse Hungersnot, 36 and documents no. 29-30, 33, 38, 323-328.

57 See e.g. Lieffländische Landes-Ordnungen, 678-679.

58 Liiv, O. Die grosse Hungersnot, 33, 41, 44, 50-1. 
In these years, as a rule, the peasants were not able to repay the advances given and also became indebted for their customary and state dues. The peasants' debts to the manors increased enormously. Naturally, such a state in turn caused the lords of the manor difficulties to which they repeatedly called the government's attention in their supplications. Besides, it has to be considered that the government was very interested in receiving the taxes in time since at the same time crops had also failed in Sweden and in Finland, which suffered the most, ${ }^{59}$ and the lacking corn was imported to both countries precisely from the Baltic provinces. Thus, in 1696 the governor-general of Livonia E. Dahlberg finally issued a decree to exhort the peasantry to fulfil their commitments. On that account the decree demanded that the whole peasantry, in particular the wealthy, had to pay obediently and unforcedly all their duties as far as possible to the leaseholder or possessor of the manor. At this, E. Dahlberg pointed out that the peasants had this on their own conscience: Each peasant is all the more obliged to do this out of the highest fairness if he thinks of how so far in these hard years the leaseholder has been using all his means in order to pay rent as well as help peasants with bread and seed corn in their need, and to conserve them. ${ }^{60}$

Only a little earlier the governor-general E. Dahlberg had sent a letter to king Charles XI about the province's extreme want and indescribable misery owing to a succession of crop failures. In this E. Dahlberg also mentions that the leaseholders of the crown manors had been obliged to give away to tradesmen all they had, so as to assist themselves and their peasants with bread- and seed-corn and to pay rent since their fields had yielded not much or nothing and the peasants had not been able to give anything. ${ }^{6}$

Although the year 1697 did not bring any relief, E. Dahlberg in Riga issued again a decree similar to the previous year's at the beginning of October. As the time had again arrived when peasants had to pay their duties with debts and advances, they were again encouraged to fulfil their commitments, neither dodging nor concealing their harvest, or just carousing and wasting that year's harvest. Once more E. Dahlberg appealed to the peasantry with an argument based on the idea of reciprocity: In consideration that the advance and other assistance provided to them [the peasants] for their meagre upkeep in those miserable times was given with a willing and compassionate heart, therefore they are also liable in turn to refund it with gratitude. ${ }^{62}$

If in spring 1696 the manors were still able to support their peasants, providing corn for bread and sowing, then already by autumn of the same year the estates

59 See Jutikkala, E. The great Finnish famine in 1696-97. - The Scandinavian Economic History Review, 1955, 3, 48-63; Abel, W. Agrarkrisen und Agrarkonjunktur. Eine Geschichte der Landund Ernährungswirtschaft Mitteleuropas seit dem hohen Mittelalter. 3rd edn. Hamburg and Berlin, 1978, 181.

60 Lieffländische Landes-Ordnungen, 660-665.

61 Livländischer General-Gouverneur aus der schwedischen Zeit (1570-1710): Concepta Octobris 1696. EHA, 278-1-IV: 34/4, ff. 28r-30v.

62 Lieffländische Landes-Ordnungen, 686. 
revealed an increasing lack of corn reserves. ${ }^{63}$ There were even some leaseholders of crown manors who had pawned their silver dinner service and jewels to the townstraders in order to procure corn for their peasants. ${ }^{64}$ Some leaseholders of the crown estates indicated in their supplications to the governor-general that saving the peasants had brought them to total ruin. ${ }^{65}$ As is known, through the great Reduktion of the 1680s, over 80 per cent of all the possessions in Livonia had gone back into the hands of the state. Therefore the government's interest in preserving the peasants of the province had noticeably increased. The obligation of the leaseholders of all crown estates to provide the peasants with assisting bread- and seedcorn was put directly down in lease contracts.

The years of the Great Famine demonstrated clearly that in the case of more severe hardship even manors could not cope with supplying the necessary corn. In normal years it was usually not a problem for a manor to take into consideration the needs of the peasants, in addition to its own consumption and sowing and putting the surplus on the market, but the situation was different in the cases of more extensive crop failures. There were no bigger stocks of reserve corn on the estates.

Thus, an acute discussion about the possibilities of creating such stores of reserve corn started in Livonia in the late 1690s. The initiative came from the governor-general E. Dahlberg in 1698. In July of the same year the King in Stockholm eventually ordered granaries in Livonia to support the province's population in cases of crop failure, and demanded from E. Dahlberg a resolution of the problem of how to put it into practice. A provisional project was prepared already by the beginning of 1699 and was submitted to Stockholm. ${ }^{66}$

However, the final confirmation by the King lingered, and then was not decided before the Northern War. In fact, a demand for the obligatory maintenance of corn reserves for the manors in Livonia was not put into operation before 1763 when the problem of local reserve corn had again risen on the agenda, but then already without any direct connections with E. Dahlberg's project. Only since then every landlord had to start keeping 20 bushels (ca 1380 l) of rye from every revision haken up to next harvest. This reserve corn (Reservatkorn) was then to be distributed on loan to the peasants in case of starvation or lack of seed-corn in spring. ${ }^{67}$

63 Liiv, O. Die grosse Hungersnot, 50.

64 Ibid., 51.

65 See e.g. LSHA, 7349-1-223, 630.

66 E. Dahlberg till Kongl. May., 30.03.1699. RA, Livonica II, vol. 343; see also Liiv, O. Die wirtschaftliche Lage des estnischen Gebietes am Ausgang des XVII Jahrhunderts. I: Allgemeiner Überblick, Getreideproduktion und Getreidehandel. Tartu, 1935, 238-239.

67 Rigischer General-Gouverneur (1649-1787): Патенты и публикаты (1761-1765). ЕНА, 279-1-585, f. 174r-174v; see also Laur, M. Eesti ala valitsemine, 165; Traat, A. Vallakohus Eestis: 18. sajandi keskpaigast kuni 1866 . aasta reformini. [The peasants' community court in Estonia: from the middle of the 18th century to the reform of 1866.] Tallinn, 1980, 111. 


\section{CONCLUSION}

It was a general expectation of the peasants that the lord of the manor provided them with the bread- and seed-corn, and waived customary dues in hard times. In Livonia, however, the landlords' subsistence guaranty did not mean direct assistance to the peasantry, as according to many social reciprocity models offered in the literature might suppose, but it was done, as a rule, only through giving advance loans and allowing arrears. Similarly in the rural economy of western Europe credit played an important role and agricultural production depended on it to a large degree. Thus, serf-peasant was still a tenant farmer who had to produce and provide his own means of livelihood, which established one of the main distinctions from slave societies where the issue of credit relations would be out of the question and the subsistence support represented an elementary state of affairs.

The manor played a major role in maintaining the peasantry. At the same time, the credit relations between manor and peasant benefited both parties - it helped the peasants overcome hard times and simultaneously the manor preserved in this way its economic capacity. However, in spite of the usual practice, it does not mean that the credit support mechanism functioned always or that the lord of the manor came every time to the peasant's rescue in cases of hardship. In particular, in the periods of starvation, as the years 1695-1697 in Livonia, the death rate and the number of deserted farmsteads was still high. The fact was that by the end of the seventeenth century there was no functioning system of collecting reserve corn in Livonia that could guarantee the necessary corn during severe hardship. In practice such a system was put into operation step-by-step only in the second half of the eighteenth century and later on such communal granaries started to play one of the central roles in the process of establishing peasants' self-governmental village community.

The fact is that in the normal years one part of the peasantry in villages was still impoverished. The main reasons for that were usually lack of land or its bad quality, duties on the household that were not adequate to its capacity, and lack of labour or animals. Frequent illnesses, flight or the death of the head of the farmstead also brought about impoverishment of a household. War and other calamities (fire, inroads) were no less devastating.

However, guarantee of subsistence had primary importance for the peasantry and so it established a basis for the peasants' attitude towards their lord of the manor. It was important for the peasantry, in connection with their expectations, of how the lord complied with their needs. The records of peasants' complaints clearly indicate that the peasants hoped for credit that was regarded as a help, and they also expected their lord to reduce their dues in bad years. In return the lord could earn the peasants' approval and they were not so liable to flight or resistance. The fact is that some lords were more obliging than the others. Thus, from the position of the peasants it is indeed possible to talk about the reciprocal issues in their relations with the manor. 


\section{MÕISAPOOLNE ABI TALURAHVALE SUBSISTENTSIKRIISIDE KORRAL LIIVIMAAL 17. SAJANDIL}

\section{Marten SEPPEL}

Käesolev artikkel püüab 17. sajandi Liivimaa näitele toetudes analüüsida mõnikord ajalookirjanduses ettetulevat väidet, et mõisnikul lasus kohustus talupoegadele raskuste ehk nn subsistentsikriiside korral abi anda (tuntud ka kui eestkostekohustus). Mida see aga tegelikult endast kujutas ja kuidas see funktsioneeris? Seejuures on huvipakkuv heita pilk selle fenomeni sotsiaalsetele ja mentaalsetele aspektidele.

17. sajandil olid subsistentsikriisid külaühiskonnas sagedased ja eriti teravaks muutus olukord nälja-aastatel 1695-1697. Mõisate vastav allikmaterjal nätab, et tõepoolest raskustesse sattunud talupidamistele andsid mõisad seemne- ja leivavilja ning sageli ka loomi, samuti sularaha ja muud hädatarvilikku. Kõiki selliseid "abiandmisi" tuleb aga ikkagi vaadelda üksnes mõisa ja talu vaheliste krediidisuhetena, kuna enamasti oli tegemist toetuslaenudega, mida talupojad pidid hiljem tagasi maksma.

Kõigele vaatamata oli mõisast saadav laen talu majapidamisele tähtis, kusjuures selline väljakujunenud krediidimehhanism polnud kasulik mitte ainult talupidamistele, vaid ka mõisatele enestele, kuna talupidamiste mittelaostumisega säilitati oma majanduslik tulu.

Mõisast saadaval abil oli oma osa ka talupoegade mõisnikusse suhtumise kujundajana. Kaebekirjadest selgub korduvalt, et mõisniku abi ikalduste või muude õnnetuste korral peeti üldiselt väga oluliseks.

Mõisa ja talu vaheline krediidimehhanism ei toiminud aga alati. Lisaks sellele, et mitte kõik mõisad ei tegutsenud aktiivsete võlausaldajatena, said olulisteks katsumusteks suuremad nälja-aastad (nt 1695-1697), mis avaldasid olulist mõju ka mõisate toimetulekule. Sajandi lõpu suure nälja aastatel oli mõisate võimalus talupoegi toetada väikene. Probleemiks oli ka asjaolu, et mõisates puudusid suuremad viljareservid. Selliste tagavarade kogumise kohustus tõusiski päevakorrale kahel viimasel aastal enne Põhjasõda, kuid lõplik otsus võeti vastu alles 1763. aastal. 